\title{
Development Of The Adventure Of Element Based On Role Playing Game As A Learning Media On Element Chemistry Matter
}

\author{
Aprianto, Achmad Lutfi \\ Surabaya State University \\ Surabaya, Indonesia \\ achmadlutfi@unesa.ac.id
}

\begin{abstract}
The aim's of this research was to develop The Adventure of Element based on Role Playing Game as a learning media on element chemistry matter. The feasibility of a game that developed assessed from criteria the validity, practicality, and effectiveness. This research used Research and development (R\&D) model that limited until the stage of the preliminary field. The feasibility of a game in terms of validity is obtained based on an asessment by validator consisting of two chemistry lecturers and one chemistry subject teacher. The validation by experts about the content validity and construct validity obtained a percentage in a row that is $90 \%$ and $87,7 \%$ of the category is very valid. The feasibility of the practicality criteria assessed from responses of a student who get a positive response of $94 \%$ with a very practical category, supported by the observation of student activities during learning that obtained average relevant activity $94,6 \%$ on very good interpretation. The feasibility of effectiveness criteria assessed from the result of post-test obtained the average percentage of $89,9 \%$ and student classical completeness obtained percentage of $100 \%$ with the category is very effective.
\end{abstract}

Keywords - The Adventure of Element, learning media, RPG (Role Playing Game), element chemistry.

\section{INTRODUCTION}

Chemistry is one of the subjects in the Mathematics and Natural Sciences specialization group based on the 2013 curriculum. Chemistry also become one of a difficult lesson for students. This is related to the characteristics of chemistry itself In Chemistry learning at Senior High School level, the Elemental Chemistry material is taught in class XII even semester with basic competencies 3.7 which is analyzing abundance, tendency of physical properties and chemical properties, benefits, impacts, the process of making main class elements (halogen, alkali, and alkaline earth). Characteristics of the Elemental Chemistry material are analytical and application. Although the material is quite interesting and quite easy compared to other materials, students of class XII are still constrained in learning Chemistry Element because of the vast and very large material coverage. Learners are required to learn a lot of learning material and can plan their learning well so that they can study efficiently [1].

Based on the pre-research questionnaire in the state of Senior High School 1 Blitar and state of Senior High School 1 Sambit Ponorogo, more than $40 \%$ of students had difficulty in learning the Elemental Chemistry material. students have learning difficulties which are difficult to memorize and understand the material. As many as $35.3 \%$ of students of SMAN 1 Blitar also found it difficult to memorize and $29.4 \%$ of students had difficulty understanding the same material. While in state of Senior High School 1 Sambit, 36.4\% of students stated that it was difficult to memorize and 54.5 students had difficulty understanding the material. The results of the interview with the teacher of state of Senior High School 1 Blitar explained that the Elemental Chemistry material had a short learning time while the material learned was very large. Short learning time occurs because class XII students in the second semester will take the National Examination material enrichment. So that teachers often give homework as independent learning at home.

The way to solve the problem is the teacher must provide new motivation and stimulation to increase students' interest. Therefore, teachers can use the the learning media to increase students' learning interest. Based on the pre-research questionnaire in the state of Senior High School 1 Blitar, $61.5 \%$ of students said that in the learning process using powerpoint edia, while in the state of Senior High School 1 Sambit Ponorogo $90.9 \%$ of students stated that in the learning process using student worksheets as media learning. Other interactive learning media are needed to improve students' understanding and as an independent learning media in the Elemental Chemistry material.

One interactive learning media is computer-based media. This media is considered effective as a learning media that can improve student learning outcomes. Computer-based media can combine text, audio, video, graphics, and animation so that it is suitable for all learning styles of different students. Interactive learning media can fulfil the learning criteria in the Minister of Education and Culture Regulation number 22 of 2016 which states that the learning process is organized interactively, inspiring, fun, challenging, motivates students to actively participate, and provides sufficient space for initiative, creativity, and independence according to the talents, interests, and physical and psychological development of students . Interactive learning media can also be in the form of game media [2].

Game media is a learning media that can improve students' understanding by using an interesting and fun way. The goal is that students are not depressed and forced to understand a new information or new knowledge. Game media can also be used to assess student learning outcomes [3], so that the use of game media is needed to increase students' understanding. Computer-based game media is one of the game media that can be used practically and effectively.

Based on a pre-research questionnaire in the state of Senior High School 1 Blitar and state of Senior High School 1 Sambit Ponorogo, more than $80 \%$ of students claimed to 
like playing computer games. Students at the high school level include as the category of teenagers, where they still like to play, both traditional games up to online games that are now very popular among students in junior and senior high school. Online game players have an average age of 1230 years with a percentage of $80 \%$ dominated with $12-21$ years and included in the category of teenagers [4]. From the survey results, it can be seen that students in high school enter the age of the category who like to play online games. Students at this level can spend hours just to complete a game mission.

Some types of games include puzzle games, adventure games, action games, Role Playing Games (RPG), a simulation game, and many more. However, the Role Playing Game (RPG) genre game is most favored by gamers in Indonesia. This genre game is a game where the players play the role of imaginary characters in an adventure story, where players will indirectly understand the storyline and messages delivered in RPG genre games [4]. In the results of the pre-study questionnaire in the state of Senior High School 1 Blitar, $26.7 \%$ of students admitted that they liked the RPG game genre. There are so many uses of RPG genre games. RPG genre games can be used in various fields begin from use in therapy, soft skill development, to use an interactive learning media. If the RPG genre game is used as a learning media, students can learn independently at home. RPG genre game in the field of education can be used as a media to help develop social attitudes, change behavior, control emotions, develop students' creativity, and tell history [5].

Therefore, a new innovation by utilizing the RPG genre game is very necessary. Educational games, especially in chemistry learning with the type of game Role Playing Game (RPG) can be used as a learning media that suits the needs of students in understanding the chemical concepts of elements and as a media of self-learning. This game is one of the

of Assessmentmedia adapted from a combination of Final Fantasy III and earthbound games as RPG characteristic. This game could be associated with the element chemistry material so that it can be used by students to learn and practice material chemistry in order to improve student learning outcomes. Based on the above problems, the game developed by researchers as a learning media in the Element Chemistry material was named The Adventure of Element. In this study aims to describe the feasibility of the game The Adventure of Element developed.

\section{METHODS}

This research is a development research that develops games as learning media using the design of Research and Development (R \& D) development [6]. The implementation phase in this study is only limited to the fourth stage or limited trials. The development design used consists of three main stages, the preliminary study stage, planning study, and development study. The preliminary study phase consists of problem identification and data collection. Planning study is the stage of data collection as material for product design. The development study phase includes product design, review, design revision, design validation, and limited trials. The target of this research is the game The Adventure of Element as a learning medium in the elemental chemical material.

The research subjects were 15 students of class XI MIPA 1 in the state of Senior High School 1 Sambit
Ponorogo in the second semester and had received the Material of the Periodic System of Elements. The instruments used in this study include review sheets, validation sheets, student questionnaire responses, student activity observation sheets, and pretest-posttest questions. Game product design that has been completed as the first draft will be reviewed by a chemistry lecturer. The review was carried out to get input and suggestions from reviewers as a game improvement material developed. The results of the review will be processed with descriptive analysis techniques. The revision of the first draft was carried out according to the input and suggestions from the reviewers. The results of the revision named the second draft. The second draft produced than will be validated by two chemistry lecture of Surabaya State University and one chemistry teacher from the state of Senior High School 1 Sambit Ponorogo. Validation results are analyzed for each component. The percentage of validated data is analyzed based on the Likert scale, as shown in Table 1 below:

TABLE I. LIKERT SCALE

\begin{tabular}{|c|c|}
\hline Assessment & Category \\
\hline Very good & 5 \\
\hline Good & 4 \\
\hline Enough & 3 \\
\hline Less & 2 \\
\hline Very less & 1 \\
\hline
\end{tabular}

Enter the validation score, then interpret it into the validation assessment as in Table 2 below:

TABLE II. PERCENTAGE OF ASSESSMENT

\begin{tabular}{|c|c|}
\hline Percentage (\%) & Assessment \\
\hline $81-100$ & Very valid \\
\hline $61-80$ & Valid \\
\hline $41-60$ & Fairly valid \\
\hline $21-40$ & Less valid \\
\hline $0-20$ & No valid \\
\hline
\end{tabular}

The game that has been developed is valid if it reaches a percentage of $\geq 61 \%$ [8]. The game that has been validated later will get a limited trial to 15 students of class XI MIPA 1 at the state of Senior High School 1 Sambit Ponorogo. After a limited trial, the pretest and posttest will be conducted. It is used as a benchmark for assessing student learning outcomes. The percentage of student learning outcomes is calculated using the following formula.

\section{Percentage of values obtained by students $=$ $\frac{\text { number of correct questions }}{\text { total number of questions }} \times 100 \%$}

Students stated to have completed learning outcomes if they have understood the competencies and indicators as well as learning objectives with minimum learning outcomes completeness criteria for chemistry subjects. The game stated to be significantly effective if the percentage of students who complete it reaches $>81 \%$. Based on the results of the analysis of learning outcomes, categories will be obtained as shown in Table 3 below. 
TABLE III. INTERPRETATION CRITERIA SCORE

\begin{tabular}{|c|c|}
\hline Percentage (\%) & Category \\
\hline $81-100$ & Very Effective \\
\hline $61-80$ & Effective \\
\hline $41-60$ & Effective enough \\
\hline $21-40$ & Less effective \\
\hline $0-20$ & Not Effective \\
\hline
\end{tabular}

Other data obtained in the study are the results of the questionnaire responses of students and supported by the activities of students to find out the practice of the game developed. The results of the questionnaire responses of students were analyzed using descriptive analysis techniques based on the Guttman Scale calculation as shown in Table 4 below.

TABLE IV. GUTTMAN SCALE

\begin{tabular}{|c|c|}
\hline Assessment & Score \\
\hline Yes & 1 \\
\hline No & 0 \\
\hline
\end{tabular}

The percentage results are then interpreted according to the following Table 5:

TABLE V. INTERPRETATION OF STUDENT RESPONSE SCORE

\begin{tabular}{|c|c|}
\hline Percentage (\%) & Assessment \\
\hline $0 \%-20 \%$ & Very practical \\
\hline $21 \%-40 \%$ & Practical \\
\hline $41 \%-60 \%$ & Practical enough \\
\hline $61 \%-80 \%$ & Less practical \\
\hline $81 \%-100 \%$ & Not practical \\
\hline
\end{tabular}

Based on the students' response criteria, games that have been developed are practical if the percentage obtained is $>61 \%$ [7]. The response of students is supported by observational data of student activities during the learning process. The data is filled by an observer. The activities of students are good and support the effectiveness of the application of the game as a learning medium if the percentage of student activities that are relevant is greater than the activities of students who are not relevant.

\section{RESULT AND DISCUSSION}

This study aims to describe the feasibility of the game The Adventure of Element based on Role Playing Game as a learning medium in the Elemental Chemistry material which is reviewed based on validity, practicality and effectiveness.

\section{A. Game Validity}

The validity of The Adventure of Element game that has been developed was obtained through a validation process by validator consist of two chemistry lecturers and one chemistry teacher. Before the validation stage, the first draft was has been reviewed before by a chemistry lecturer to get suggestions and comments for the improvement of the game developed.

Based on the results of the review from the reviewers. These suggestions and inputs are then used to improve the game so as to produce a second draft which will then be validated.

In the validation process, the game is assessed based on the criteria of content validity and construct validity [8].
Validation results are then analyzed and presented by each component using a Likert Scale. Following are the details of the game validity data that have been developed.

1) Content Validity

The results of content validity from the validators are described in Table 7 below.

TABLE VI. RESULTS OF CONTENT VALIDITY OF THE GAME THE ADVENTURE OF ELEMENT

\begin{tabular}{lll}
\hline Assessed Aspect & $\begin{array}{l}\text { Percentage } \\
(\%)\end{array}$ & Category \\
\hline Concept truth & 80 & Valid \\
Have a purpose & 100 & Very valid \\
\hline
\end{tabular}

Based on Table 7 game The Adventure of Element which has been developed meets the first aspect of content validity, namely Concept truth on the indicator "Chemical Concepts of Elements in the game is right" get a percentage of validity of $80 \%$ which means in the valid category because it has a percentage of $\geq 61 \%$ or entered in the range of $61 \%-80 \%$ which means the concept of Chemistry The elements in the game are considered correct.

The Adventure of Element has also been developed that fulfills the second aspect of content validity, namely have a purpose on the indicator "The material in the game matches the learning objectives or indicators" gets a percentage of validity of $100 \%$ which can be categorized as very valid because it has a percentage of $\geq 81 \%$ or entered in the range of $81 \%-100 \%$, which means that the material in the game is very suitable with the objectives or indicators of learning. Sadiman (2011) states that one component in the game is the existence of certain goals to be achieved [3]. Therefore, the assessment indicator in this aspect intends that every chemical element in the game is in accordance with the objectives and indicators of learning to be achieved. construct validity

2) Construct Validity

The results of the construct validity of the validators are described in Table 8 below.

TABLE VII. RESULTS OF CONSTRUCT VALIDITY OF THE GAME THE ADVENTURE OF ELEMENT

\begin{tabular}{|c|c|c|c|}
\hline Assessed Aspect & Indicator Assessment & $(\%)$ & Category \\
\hline $\begin{array}{l}\text { Characteristics of } \\
\text { science }\end{array}$ & $\begin{array}{l}\text { There are investigative } \\
\text { activities }\end{array}$ & 80 & Valid \\
\hline \multirow{2}{*}{$\begin{array}{l}\text { Encourage } \\
\text { developing special } \\
\text { skills }\end{array}$} & $\begin{array}{l}\text { Develop computer } \\
\text { operating skills }\end{array}$ & 93 & $\begin{array}{l}\text { Very } \\
\text { valid }\end{array}$ \\
\hline & $\begin{array}{l}\text { Develop playing skills } \\
\text { using computers }\end{array}$ & 93 & $\begin{array}{l}\text { Very } \\
\text { valid }\end{array}$ \\
\hline $\begin{array}{l}\text { Conformity with the } \\
\text { characteristics of } \\
\text { students }\end{array}$ & $\begin{array}{l}\text { Suitable with the age of } \\
\text { students }\end{array}$ & 80 & Valid \\
\hline Have rules & $\begin{array}{l}\text { There are guidelines } \\
\text { (game manual) or rules } \\
\text { of play }\end{array}$ & 87 & $\begin{array}{l}\text { Very } \\
\text { valid }\end{array}$ \\
\hline Guiding character & $\begin{array}{l}\text { There are instructions for } \\
\text { completing the game } \\
\text { (narration) }\end{array}$ & 87 & $\begin{array}{l}\text { Very } \\
\text { valid }\end{array}$ \\
\hline $\begin{array}{l}\text { There is a standard } \\
\text { of success }\end{array}$ & $\begin{array}{l}\text { There is a condition to } \\
\text { proceed to the next level }\end{array}$ & 93 & $\begin{array}{l}\text { Very } \\
\text { valid }\end{array}$ \\
\hline $\begin{array}{lr}\text { Challenging } & \text { and } \\
\text { involving } & \text { active } \\
\text { students } & \\
\end{array}$ & $\begin{array}{l}\text { Encourage students to } \\
\text { play while learning }\end{array}$ & 93 & $\begin{array}{l}\text { Very } \\
\text { valid }\end{array}$ \\
\hline Provide feedback & There are penalties if & 93 & Very \\
\hline
\end{tabular}




\begin{tabular}{|c|c|c|c|}
\hline \multirow[t]{3}{*}{ Assessed Aspect } & Indicator Assessment & $(\%)$ & Category \\
\hline & you fail & & valid \\
\hline & $\begin{array}{l}\text { There are prizes when } \\
\text { experiencing success }\end{array}$ & 87 & $\begin{array}{l}\text { Very } \\
\text { valid }\end{array}$ \\
\hline $\begin{array}{l}\text { Have an element of } \\
\text { decision making }\end{array}$ & $\begin{array}{l}\text { Options are available in } \\
\text { answering or stepping to } \\
\text { play (there are } \\
\text { alternative activities that } \\
\text { must be chosen) }\end{array}$ & 87 & $\begin{array}{l}\text { Very } \\
\text { valid }\end{array}$ \\
\hline \multirow[t]{2}{*}{$\begin{array}{l}\text { Display as a learning } \\
\text { media }\end{array}$} & $\begin{array}{l}\text { The font size used is } \\
\text { appropriate }\end{array}$ & 93 & $\begin{array}{l}\text { Very } \\
\text { valid }\end{array}$ \\
\hline & $\begin{array}{l}\text { The animation used is in } \\
\text { accordance with the } \\
\text { content }\end{array}$ & 73 & Valid \\
\hline \multirow[t]{2}{*}{ Software engineering } & The game is easy to play & 73 & Valid \\
\hline & $\begin{array}{l}\text { The game is easy to } \\
\text { install }\end{array}$ & 93 & $\begin{array}{l}\text { Very } \\
\text { valid }\end{array}$ \\
\hline \multirow[t]{2}{*}{$\begin{array}{l}\text { Audiovisual } \\
\text { communication }\end{array}$} & $\begin{array}{l}\text { There is a connection } \\
\text { between narration, sound } \\
\text { effect, backsound, and } \\
\text { music }\end{array}$ & 93 & $\begin{array}{l}\text { Very } \\
\text { valid }\end{array}$ \\
\hline & $\begin{array}{l}\text { There is harmony } \\
\text { between the background } \\
\text { design and the placement } \\
\text { of text and color }\end{array}$ & 93 & $\begin{array}{l}\text { Very } \\
\text { valid }\end{array}$ \\
\hline
\end{tabular}

From Tables 6 and 7 the results of the content and construct validity in the game get the results of each of $90 \%$, and $87.7 \%$ and the average validity of $88.85 \%$ so that it is categorized as very valid.

\section{B. Game Practicality}

The practicality of the game developed was reviewed based on the responses of students and supported by the activities of students during learning using the game The Adventure of Element developed. The response questionnaire contains a number of positive and negative questions with the choice of "Yes" or "No" answers distributed after the implementation of learning using the game developed for a number of 15 trial students. The game developed is said to be practical if the data from the questionnaire responses of students show $\geq 61 \%$ positive response [8]. The following are the results of the student response questionnaire.

TABLE VIII. STUDENT RESPONSE RESULTS

\begin{tabular}{|c|c|c|c|c|}
\hline \multirow{2}{*}{ No. } & \multirow{2}{*}{$\begin{array}{l}\text { Positive / Negative } \\
\text { Statement }\end{array}$} & \multicolumn{3}{|c|}{ Assessment } \\
\hline & & amount & $(\%)$ & Category \\
\hline \multicolumn{5}{|c|}{$\begin{array}{l}\text { Knowing the game The Adventure of Element can increase students } \\
\text { curiosity }\end{array}$} \\
\hline 1. & $\begin{array}{l}\text { The Adventure of } \\
\text { Element game is very } \\
\text { fun }\end{array}$ & 15 & 100 & $\begin{array}{l}\text { Very } \\
\text { Practical }\end{array}$ \\
\hline 2. & $\begin{array}{l}\text { Appearance/design of } \\
\text { the game The } \\
\text { Adventure of Element is } \\
\text { interesting }\end{array}$ & 15 & 100 & $\begin{array}{l}\text { Very } \\
\text { Practical }\end{array}$ \\
\hline \multicolumn{3}{|c|}{ Average percentage } & 100 & $\begin{array}{l}\text { Very } \\
\text { Practical }\end{array}$ \\
\hline \multicolumn{5}{|c|}{ Knowing the clarity of how to play The Adventure of Element game } \\
\hline 3. & $\begin{array}{l}\text { I understand the steps of } \\
\text { using the game The } \\
\text { Adventure of Element }\end{array}$ & 11 & 73 & Practical \\
\hline 4. & $\begin{array}{l}\text { The language used in } \\
\text { the game The } \\
\text { Adventure of Element is } \\
\text { easy to understand }\end{array}$ & 12 & 80 & Practical \\
\hline
\end{tabular}

\begin{tabular}{|l|l|l|l|l|}
\hline \multirow{2}{*}{ No. } & Positive / Negative & \multicolumn{3}{|l|}{ Assessment } \\
\cline { 2 - 5 } & Statement & amount & (\%) & Category \\
\hline 5. & $\begin{array}{l}\text { The material in the } \\
\text { game The Adventure of } \\
\text { Element is easy to } \\
\text { understand }\end{array}$ & 14 & 93 & $\begin{array}{l}\text { Sangat } \\
\text { Praktis }\end{array}$ \\
\hline Average percentage & 82 & $\begin{array}{l}\text { Very } \\
\text { Practical }\end{array}$ \\
\hline Knowing that the Adventure of Element game is easy to use \\
\hline 7. & $\begin{array}{l}\text { In playing the game The } \\
\text { Adventure of Element, } \\
\text { the game runs smoothly }\end{array}$ & 15 & 100 & $\begin{array}{l}\text { Very } \\
\text { Practical }\end{array}$ \\
\hline 8. & The button runs well & 15 & 100 & $\begin{array}{l}\text { Very } \\
\text { Practical }\end{array}$ \\
\hline Average percentage & 100 & $\begin{array}{l}\text { Very } \\
\text { Practical }\end{array}$ \\
\hline
\end{tabular}

Based on the results of the questionnaire responses of students, the game that has been developed as an average response of $94 \%$ or categorized as very practical. The questionnaire data is supported by observations of student activities during the learning process using games developed.

Based on data from students' activities observation it can be seen that during the limited trial activities using the game The Adventure of Element as a learning media in the material Chemistry Elements, showing a result that activity of students percentage is bigger than before with an average percentage of $94.6 \%$.

This result shows that students during the learning process are very enthusiastic and interested when playing the game The Adventure of Element developed, so that it can be concluded that the questionnaire responses are filled by students in accordance with their real opinions and circumstances relevant to the results of the observed activity.

\section{Game Effectiveness}

The effectiveness of The Adventure of Element game as learning media on elemental chemistry material is measured based on the results of the pretest and posttest. The effectiveness of the game The Adventure of Element is known from the increasing of learning outcomes score where the post-test score is greater than the pre-test value. Analysis of the results of pre-test and post-test know from individual completeness and classical completeness. Students totally complete if they get a percentage of $\geq 75 \%$ and classical completeness with a percentage of $\geq 80 \%$. The following are the results of the pre-test and post-test of students presented in the form of graphs in Figure 1.

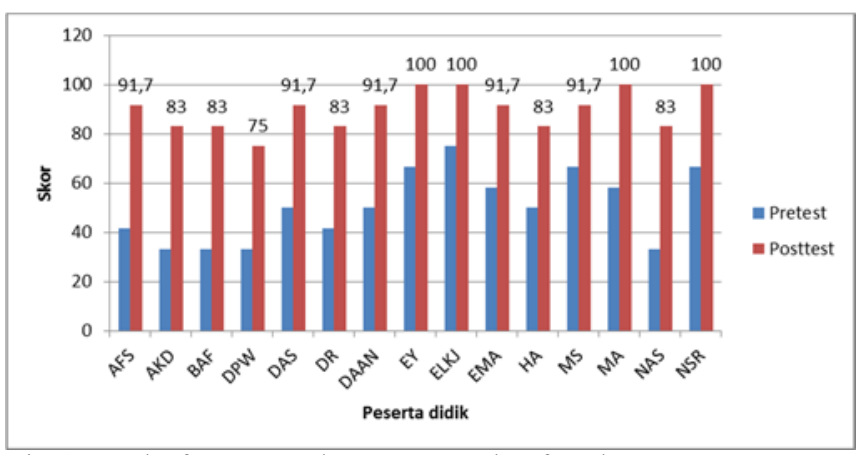

Fig. 1. Graph of Pre-test and Post-test Results of Students 
Learning outcomes of individual learners can be seen on the learner with DPW initial get a percentage value of $33.3 \%$ at the pre-test and $75 \%$ the time post-test where the value of the thoroughness of the limit value completeness, but has a higher increase in learning outcomes compared to students with ELKJ initial who get a percentage of $75 \%$ at pre-test and $100 \%$ at post-test. This can occur if the learning outcome assessment instrument has a certain limit, where the assessment instrument for post-test learning outcomes and pre-test in this study only has 12 multiple-choice questions. if the learning outcome assessment instrument is improved by the number of items that are more numerous, it can measure the improvement of the actual learning outcomes for students with a percentage of $100 \%$.

Based on the graph of the completeness of individual learning outcomes students can also be seen that all students experience an increase in the percentage of grades and get a percentage value of $\geq 75 \%$ or can be said to reach the percentage of completeness. According to Dimyati (2006) learning outcomes are results achieved in the form of scores after being given a test of learning outcomes at the end of each lesson. The values obtained by students become a reference to see the mastery of students in receiving learning material [9]. It can be said, in this study all students can receive the Elementary Chemistry material by using the game The Adventure of Element as a learning medium.

Based on the results of the Pre-testand Post-test of Learners in Figure 1, there is an increase in the learning outcomes of students individually after using the game The Adventure of Element. This shows that the game The Adventure of Element can have a good influence on student learning outcomes. The completeness of the learning outcomes of students has increased from $6.7 \%$ to $100 \%$ so that it can be said that the game The Adventure of Element is very effective to be used as a learning medium in the Element of Chemistry material.

\section{Conclusion}

Based on the results and discussion of this study, it can be concluded that the game The Adventure of Element that has been developing is feasible to be used as a learning media because it has met all the feasibility criteria, follows:

1) The Adventure of Element game as a learning media in the Chemistry Element based on the validity aspect was declared to be very feasible, based on the results of the validator's assessment of content validity and construct validity, the results were $90 \%$, and $87.7 \%$ and the validity average was $88,85 \%$.

2) The Adventure of Element game as a learning media in the Element Chemistry material based on practical aspects is very practical, based on the students' response to the game The Adventure of Element as a learning media in the Element Chemistry material through a questionnaire given a positive response with an overall percentage of $94 \%$ with a very practical category, supported by observations of students' activities during learning by obtaining an average of relevant activities of $94.6 \%$ with very good interpretations.

3) The Adventure of Element game as a learning media in the Chemistry Element element based on the effectiveness aspect is effective showed by the results of the post-test and the completeness of the students. The average percentage obtained by students is $89.9 \%$. All students individually get a percentage of completeness value of $\geq 75 \%$ and classical completeness of $100 \%$ with a very effective category. So that the game The Adventure of Element that was developed effectively can be used as a learning media for students in the Elemental Chemistry material.

\section{ACKNOWLEDGMENT}

Thank you to Dr. Achmad Lutfi, M.Pd. who have given directions and suggestion in the preparation of this article.

\section{REFERENCES}

[1] Rusmansyah and Irhasyuarna, Implementation of the Community Technology Science Approach (STM) in Chemistry Learning in Banjarmasin City 1 Public High School (Implementasi Pendekatan Sains Teknologi Masyarakat (STM) dalam Pembelajaran Kimia di SMU Negeri 11 Kota http://www.depdiknas.go.id/jurnal/40/Implementasi\%20Pendekatan\% 20Sains-Teknologi-Masyarakat.htm accessed date 21 Oktober 2017, 2001.

[2] Kemendikbud, Regulation of the Minister of Education and Culture of the Republic of Indonesia Number 23 of 2016 concerning Educational Assessment Standards (Peraturan Menteri Pendidikan Dan Kebudayaan Republik Indonesia Nomor 23 Tahun 2016 Tentang Standar Penilaian Pendidikan), Jakarta: Minister of Education and Culture of the Republic of Indonesia, 2016.

[3] Sadiman, Media Education: Definition of Development, and Utilization (Media Pendidikan: Pengertian Pengembangan, dan Pemanfaatan), Jakarta: PT. Raja Grafindo Persada, 2011.

[4] Karimuddin, Amir, Agate Survey (Survei Agate). https://dailysocial.id/post/survei-agate-indonesia-menyukai-gamerpg-strategi-dan-fps, accessed date 21 Oktober 2017, 2012.

[5] Borg, W.R. \& Gall, M.D. Gall, Educational Research: An Introduction, Fifth Edition, New York: Longman, 1989.

[6] Riduwan, Research Variables Measurement Scale (Skala Pengukuran Variabel-Variabel Penelitian). Bandung: Alfabeta, 2015.

[7] https://coggle.it/diagram/WimyeaCQTwABZ0dH/t/role-playing-game accessed date 21 Oktober 2017.

[8] Plomp, Tjeer and Nieveen Nieke, Education Design Research: An Introduction, SLO: Netherlands Institute for Curriculum Development, 2013. 